\title{
Ricardo Palma: forjador de la conciencia socio-histórica del Perú
}

\author{
Eduardo Arroyo Laguna \\ Universidad Ricardo Palma \\ eduardoarroyo29@gmail.com
}

\section{Resumen}

La vida de don Ricardo Palma es una de las aventuras intelectuales más apasionantes de la historia nacional e internacional. No es solo un intelectual sino un hombre de acción, un político. Su vida lo llevará al campo de la poesía, dramaturgia, narrativa, crónica, creando las Tradiciones y convirtiéndose en la conciencia socio-histórica del Perú.

Palabras clave: Conciencia socio-histórica, acción patriótica, peruanista, limeñista.

\footnotetext{
Abstract

Ricardo Palma's life is one of the most passionate of our history. He was an intellectual besides a political, an action man. During his life he wrote poetry, journalism, theater, chronicle and Traditions, becoming in the social-historical consciousness of Perú.
}

Keywords: Historical-social awareness, patriotic action, peruanist, "limeñista". 


\section{Eduardo Arroyo Laguna}

Sociólogo, poeta, narrador, promotor cultural y periodista. Doctor en Ciencia Política y Relaciones Internacionales, directivo del Colegio de Sociólogos del Perú y de la Asociación Amigos de Mariátegui. Docente de la Universidad Ricardo Palma. 
La vida y obra de don Ricardo Palma constituye una de las aventuras intelectuales más apasionantes de la historia patria e internacional. No solo revisa la realidad nacional sino que da un testimonio de los personajes, incidentes y del humor espiritual de su época.

A lo largo del análisis de sus textos aparecen día a día episodios nunca suficientemente valorados, que este evento "Re-visión de las Tradiciones Peruanas" va sosteniendo en el tiempo. Desde que el Instituto Ricardo Palma, de la universidad que lleva el mismo nombre, se fundara en febrero de 1997 agrupando a los mejores literatos del país y del extranjero, los palmistas lo han convertido en una trinchera y baluarte de la resistencia contra el tiempo para escudriñar una de las vidas más azarosas y recias de la historia nacional así como una de sus plumas más feraces.

Palma, contador de profesión, ejerció su profesión asesorando contablemente a la Marina Mercante del Perú. Pero destaca como escritor trabajando en diversas áreas: artículos periodísticos (que los hizo y siempre combativos, y de los buenos, escribiendo ya sea con pseudónimo o con su nombre propio), poesía, narrativa, crónica, tradición y piezas de teatro.

Es eminentemente un hombre de acción, por cuanto participa desde muy joven en numerosas asonadas y golpes de estado en su vida -que va de 1833 a 1919-, llegando a ser secretario de un Presidente de la República y diplomático por designación.

Le toca vivir en años posteriores a la jura de la independencia y en una Lima melindrosa y republicana que se queda, como dice Mariátegui, entre feudal y capitalista. Los cierrapuertas de una ciudad que pendulaba entre el adormecimiento y la rebelión (de la apatía al tumulto y al bochinche) reflejaban la falta de hegemonía de una clase capitalista que lanzara un programa nacional al conjunto del país y explicara una larga 
época de anarquía militar (entre 1840 y 1860), hasta que inicia su centralidad a partir de los gobiernos de Ramón Castilla y la posterior consolidación de un primer aliento burgués con Manuel Pardo, quien verá destruidos los recursos naturales que debieron ser la base de nuestro desarrollo capitalista con la Guerra del Pacífico.

Lima, ciudad a partir de la cual Palma se relacionará con el mundo, era una aldea amurallada desde que el Virrey Duque de la Palata la encerrara allá por 1670. Poco moderna, cenáculo de chismes, dimes y diretes, de esta capital pequeña, semifeudal, fundada por un conquistador europeo y dirigida por una aristocracia que le daba un carácter endógeno, Palma asumirá muchos de los rasgos de esta ciudad-capital del Perú pero, además, será hombre de asonadas, deportaciones, de cárceles, de haber participado como senador, como cónsul, siempre sumido en la esfera intelectual, nunca regateándole nada a la vida sino dándose por entero.

Como romántico, amará la justicia, la verdad, y luchará por alcanzarla. Amará, además, la idea de una patria que estaba en proceso de constituirse. Pero hay algo especial en Palma: es vitalista, necesita de acción y por eso desde muy joven interviene en política. Siempre tomó partido y no se quedó de diletante diciendo nada más que discursos.

La suya es una acción patriótica. Cuando la patria lo convoca, Palma estará siempre al frente colocando el pecho ante la tarea que se le asigne sin regatearle nada a la vida ni lamentarse, sino abriendo camino hacia adelante. Patriota, luchador, rebelde, son rasgos de su personalidad que, a entender de Roland Forgues, lo convierten en:

Uno de los patriotas criollos más activos en defensa de la patria y de la República liberal que surge de la revolución 
por la independencia americana. Su participación en la contienda política de la época, su intensa actividad en las altas esferas del poder legislativo y ejecutivo, así como su fecunda labor cultural de reconstrucción de la Biblioteca Nacional, destruida en el momento de la Guerra con Chile, de miembro de la academia y defensor de la lengua lo colocan ciertamente entre la élite criolla más culta y avanzada en el camino de formación de la nacionalidad peruana, como revela, entre otros escritos, su epistolario (...) Sin embargo, el mismo consenso no se dará en el campo de su producción literaria en donde conservadores, liberales, radicales y revolucionarios encontrarán motivos de recuperación o de rechazo. O verán en ella los primeros rasgos de construcción de una nueva utopía nacionalista (...). (Forgues, 2016: 325).

Este es un primer rasgo que deseo destacar en este XVI Encuentro internacional "Re-Visión de las Tradiciones Peruanas". Palma luchador social es un capítulo aún no estudiado del todo y que los miembros del Instituto Ricardo Palma deberíamos revisar.

Y cuando la vida lo coloca al frente de la Biblioteca Nacional del Perú, tras los aciagos años de la Guerra del Pacífico, con unas salas de lectura que la soldadesca chilena había usado como caballerizas, burlándose del Perú, Palma, humilde, rogará a todo el mundo por libros para emprender una de las aventuras que lo tildará como el "bibliotecario mendigo".

Su propia vida es un hito de conciencia, de conformación de las identidades en el Perú y del modo como los hechos sociales, políticos y la asunción de nuestros deberes nos forjan como descubridores y hacedores de la patria. Palma es un ejemplo claro de su amor a la patria como de su entrega al trabajo político y escritural. No hay sosiego en la obra de este autor, lo que debe motivarnos a llevar su vida y obra fuera de los cenáculos literarios hacia los niños y jóvenes para que aprecien la obra de 
este prolífico autor, considerado como el mayor literato que ha producido el Perú.

\section{Palma es conocido en el extranjero}

Palma, estando vivo, llegó a ser muy conocido en el Perú y en el extranjero. Basta revisar su frondoso epistolario ${ }^{1}$ como los textos de Oswaldo Holguín Callo (200 l) para dar un testimonio de ello. Su obra se irradiará a Estados Unidos, Inglaterra, Latinoamérica, Cuba y otros puntos del planeta.

Nos contaba nuestro Rector que en uno de sus viajes a España, en un pueblo recóndito que visitaba, cuando le obsequió una obra de Palma a un lugareño, este le dijo que para él Palma era "el Cervantes del Perú". El ibérico conocía al tradicionista y no era precisamente miembro de un cenáculo literario sino hombre de campo. Si don Miguel de Cervantes recrea y crea las imágenes que pueblan las mentes de los habitantes de la península ibérica -y del mundo entero- con El Ingenioso Hidalgo Don Quijote de la Mancha y sus Novelas Ejemplares, don Ricardo Palma es autor y recreador de las imágenes que pueblan nuestra vida inconsciente, consciente $\mathrm{y}$ nuestro actuar cotidiano habiendo hecho de la historia una herramienta de acción, de estudio, de reflexión. Las imágenes que ha creado con sus textos han dado la vuelta al mundo y, en el caso peruano, han cimentado la forja de una conciencia socio-histórica de nuestro país.

A Palma lo han estudiado tirios y troyanos, nativos del país y extranjeros y todos siempre reivindican algún aspecto de su obra porque siendo esta vastísima se puede tratar desde diferentes ángulos y ópticas. De un lado el Palma político luchando en

I Revisar los cuatro tomos de Epistolario General editados por la Universidad Ricardo Palma, Editorial Universitaria. 
el Congreso como senador por la provincia litoral de Loreto, y que, a la vez, era secretario de la Presidencia de la República. De otro lado el Palma marino, que era contador de la marina mercante llevando las cuentas de sus bienes.

\section{Peruanista y limeñista}

Ricardo Palma no solo definirá la peruanidad sino también la limeñidad de su tiempo. No viajó mucho por el país, asunto poco común en esos años, pero escribió sobre sus numerosos departamentos adquiriendo la información de los diarios que circulaban en la capital así como del constante carteo que mantenía con palmistas, periodistas, lugareños y peruanos de los diferentes departamentos y provincias del Perú.

Sobre Lima, dirá Raúl Porras Barrenechea en su Pequeña antología de Lima que si Pizarro fue el fundador oficial, formal, de la ciudad capital, Ricardo Palma es el fundador real.

Las imágenes que pululan sobre la urbe en nuestras mentes, sea de virreyes, presidentes, incas, como de gente de la calle, indios, mestizos y criollos, negritas quimbosas, negros cimarrones, analizándolos en sus espíritus pequeños, nos indican que Lima fue, desde siempre, esa ciudad de todas las sangres como bien la definiera José María Arguedas y aceptara actualmente Mario Vargas Llosa.

Los rasgos de la limeñidad serán definidos por una aristocracia conservadora y nunca por una burguesía moderna. Será más la identidad de una ciudad pequeña, de menos de cien mil habitantes -y no la de los diez millones de almas de la actualidad-, encerrada en sí misma, y nunca una ciudad abierta al gran mundo, liberal (hoy global) o mestiza, sino conservadora, amurallada. La aristocracia, buscando distanciarse del resto del país, al que siempre consideraron 
como una provincia, y Lima como la Arcadia Colonial, definirá su espíritu como si fuera una entelequia fija, nunca cambiante, con una concepción estática y anquilosada de la limeñidad y del limeñismo como del limeño, protagonista de esta identidad.

Hoy hay que remarcar un Perú multicultural, multilingüe, de todas las sangres, asunto que llegó a visualizar Palma pero en su versión más urbanisa, más limeña, centrada en la ciudad capital. Pese a ello, Palma zahiere a las clases dominantes y reivindica a los de abajo representando ese espíritu criollo que ante la ausencia de una burguesía revolucionaria, moderna, y de clases medias en el poder incapaces de devenir en burguesía, resuelven su conflicto y rebeldía en alguna asonada y centralmente en el chiste y la murmuración.

\section{La Lima de Palma}

Si según Ortega y Gasset, el ser humano es uno y sus circunstancias, a Palma le toca vivir en una Lima pequeña amurallada, llena de melindres y con exceso de iglesias. Esas son las imágenes que pueblan la mente de Palma, niño en esta ciudad, nacido muy cerca de un mercadillo y al costado de una Iglesia. Por eso, Palma tomará partido por el pueblo y analizará la mentalidad popular descubriendo que va a ser a través del raje y el chisme que el pueblo erosiona las estructuras del poder de las clases dominantes ante la imposibilidad de asaltar el poder de otra forma. No teniendo otra arma que el chismorreo, la burla, el raje, el chisme, la sátira, esa será la herramienta popular para echarse abajo el tinglado de poder de la clase dominante, y será absorbida por el tradicionista convirtiéndola en herramienta central para la formación de la conciencia socio-histórica de nuestra patria. Nos dice este escritor en la introducción a las Tradiciones Peruanas completas (ordenadas cronológicamente 
por su nieta Edith Palma, su gran biógrafa), en su poema largo titulado Cháchara:

Muy poco me ha picado la tarántula

que llaman los humanos vanidad.

Yo escribo...porque sí-razón potísima, tras ella las demás están de más.

El hombre no ha de ser como los pájaros, que vuelan sin dejar su huella en pos.

¿Quién sabe si me espera fama póstuma?

De menos, ivive Dios!, me hizo Dios.

Yo sé que no se engaña, ivoto al chápiro!, de botones adentro un escritor, y sé que mis leyendas humildísimas no pueden hacer sombra a ningún sol.

iY hay tantos soles en mi patria espléndida, y tanto y tanto genio sin rival!...

Por eso yo, que peco de raquítico, les dejé el paso franco y me hice atrás.

Y pues ninguno en la conseja histórica quiso meter la literaria luz, yo me dije: -Señores, sin escrúpulo, aquí sí que no peco, aquí estoy yo.

Fue mi embeleso desde que era párvulo, más que en el hoy, vivir en el ayer; y en competencia con las ratas pérfidas, a roer antiguallas me lancé... 
Y ya en prosa, ya en verso, de mi gárrula pluma, años hace, no se escapa un iay!, y para enmascarar mi pobre espíritu recurro de la broma al antifaz...

Mis libros piedrecillas son históricas que llevo de la patria ante el altar. He cumplido un deber. Saberlo bástame. Otros vendrán después: Mejor lo harán

Ricardo Palma, Lima, mayo de 1875.

Palma se ríe de los plumíferos fariseos, que sobraban en dicha Lima como en la actual, jungla de supuestos buscadores de la verdad, cogidos unos de los otros, megalómanos en su mayoría, narcisistas a más no poder, ególatras en grado sumo.

Unos años antes de la infausta Guerra del Pacífico, Palma se regodeará de nuestra Lima que cae enamorada, cual Narciso, al verse ella misma ante un espejo; y los limeños cogen estos rasgos para justificar su egolatría. Todos estos escritores quieren llegar al Parnaso. Palma se burla de ellos con su pluma socarrona, detallando esto y cómo lo divierte en este mundillo de sables desenvainados que hacen tanto daño, riéndose de lo más sagrado, de las personalidades de estos gaznápiros, seres mediocres disputándole al destino su paso a la inmortalidad sin comprender que ese paso no se compra con lisonjas ni estando cerca del poder sino con mucho sudor, transpiración, inspiración y talento por supuesto.

Palma se divierte denunciando en tono de cháchara, como él mismo dice de este escrito embrionario, que Lima es una ciudad de borricos como de asnos emperifollados buscando todos ellos el pase a la gloria. Creen que escribir un buen texto los hará pasar a la eternidad sin reconocer ni saber por ignorancia que 
el paso a la inmortalidad lo da la calidad de la obra, la sensatez, el sentido común, una sensibilidad diferente que reconozca al hombre y a la mujer del pueblo como seres humanos, sin mancillarlos, sino creyente de sus deberes y derechos, que deben ser naturalmente felices y nosotros respetuosos de sus derechos humanos y sus deberes.

Palma, además, nos está diciendo que él se dedicó desde pequeño a roer antiguallas y en este mundo de soles donde todos creen brillar al mismo nivel que el sol astronómico -los acomplejados de siempre-, él da un paso al costado y dado que nadie hace historia toma el reto y asombra en este campo por sus crónicas que él llamará tradiciones, dándole su propio sabor e identidad a estos escritos.

La identidad plurilingüe de nuestra patria, su carácter multicultural, está tratada en cada una de sus tradiciones: ese "todas las sangres" que sabrá sintetizar Arguedas refiriéndose a todo el Perú.

Por ello en sus tradiciones -desde La Gruta de las Maravillas (ambientada en 1181) y La Achirana del Inca (que evoca el año 1412) hasta su última tradición titulada, por obvias razones, Mi última tradición- Palma tendrá siempre en mente la vida y obra de los pueblos, su idiosincrasia. Su nieta y editora, Edith Palma, una fina analista de la obra de su abuelo, compila ordenadamente sus tradiciones en orden cronológico y añade, acabadas las tradiciones, los Anales de la Inquisición de Lima, La Segunda Inquisición, La Bohemia de mi Tiempo, Recuerdos de España, Ensayos, Artículos y versos, Parrafadas de crítica, Miscelánea Epistolar y Apéndices.

Sus tradiciones, creación de un género basado en la historia, serán una suerte de crónica histórica aderezada por el ingenio, la chispa, el sabor y la inventiva de este escritor de gran calado. 
Que sea el forjador de la conciencia socio-histórica del Perú, lo dice José Gálvez en el poema introductorio a la obra editada por Edith Palma titulado A Don Ricardo Palma:

Con su varita mágica despertó del pasado

oidores y virreyes, tapadas y guerreros, dando vida a la muerte sus manos milagrosas;

abrió a nuestras miradas un inmenso Dorado, nuestro sombrío cielo tachonó de luceros y añadió a la corona de Lima una de rosas...

Curvado por la gloria, paseó en esta avenida aquel patriarca mago su ancianidad gloriosa, aquel que a nuestra historia diera vida con su alma: y aunque los tiempos pasen y cambie nuestra vida, ha de triunfar perenne, como una enseña airosa, el nombre evocativo de Don Ricardo Palma.

Añade Edith Palma que "Estos versos figuran en el busto de Palma que se encuentra en la Alameda de su nombre, en el barrio de Miraflores, Lima".

Figura, además, en estas obras completas un largo poema de José Gálvez sobre don Ricardo Palma.

Entre sarcástico y burlón con tanto escritorzuelo que puebla esta comarca, todos creyéndose soles, Palma se declara humildemente un escritor, satirizando a tantos soles en esta comarca que terminan opacando al mismo sol en su camino a esa inmortalidad tan buscada por estos bufos del alma.

Como dijera alguna vez Pablo Macera, el peruano promedio no es sol, es a lo más un relumbrón, no es luz permanente que oriente sino es solo un chispazo. 


\section{La negritud de Palma}

En este país y capital de todas las sangres, mestizo desde siempre pero en el que todos han pugnado por ser blancos, Palma ha sido zaherido tanto en el colegio como a lo largo de su vida por sus rasgos afrodescendientes. Él, hijo de una quarterona costeña, Dominga Soriano y del mestizo nacido en la sierra, Pedro Palma, ha sufrido la discriminación por su ascendencia negra. En nuestro claustro universitario tenemos un gran busto del Palma moreno, no del blanco que la historiografía oficial ha inventado en un alarde racista.

Palma no es de origen pudiente pero tampoco es de origen social pobre sino que procede de una clase media venida a menos. Nace en las fronteras de un convento, cerca de un mercadillo y en medio del bullicio del mundo popular que lo aconseja desde niño y por ello resuenan las voces populares en su obra, por lo que no aciertan quienes lo tildan de conservador. ¿De cuándo acá retratar el alma popular con tanta gracia es propio de conservadores? Es más bien un romántico liberal, revolucionario, combativo.

Oswaldo Holguín habla sobre su negritud. Nos dice que Palma soportó diversos insultos racistas de algunos detractores pero “(...) a pesar de ellos, Palma no solo no interrumpió su exitosa carrera pública, sino que, al no negar tal origen, lo asumió con entereza y, andando los años, pudo decir que en el Perú "quien no tiene de inga tiene de mandinga (...)".

Palma ha conocido a fondo la choledad, la negritud, el mestizaje que se da en los mercados, en las plazas limeñas que tanto preocuparon a Radiguet, Angrand, el conde Sartiges, Pancho Fierro, desfilando la desigualdad social, racial y todas las sangres contenidas en nuestra ciudad, desfile que se daba festivamente en las calles, plazas y cementerios. 


\section{La polémica con González Prada}

Palma y González Prada representan dos modos diferentes de mirar al país. Un afán de la feligresía alegre e irresponsable ha enaltecido a uno como liberal y moderno y a Palma como conservador.

José Carlos Mariátegui, siempre lúcido y sereno, no se dejará llevar por apasionamientos y revelará el rol de ambos.

González Prada, el de salón y gabinete, de largas y filípicas conferencias y debates, de sermones sobre la nacionalidad peruana, mientras Palma ingresa al alma nacional para hacer picadillo las contradicciones de la personalidad nacional. Lo caracteriza su chispa criolla, el espíritu retozón, ingrediente propia del alma criolla al que Palma le pone su sapiencia, su lectura.

La platea tomará partido por uno u otro sin darse cuenta que ambos son parte de un mismo proceso de configuración de la identidad nacional. Tanto Víctor Raúl Haya de la Torre como José Carlos Mariátegui procuran rescatarlo de la tentativa de recuperación conservadora emprendida por Riva Agüero y sus compañeros. Ambos ensayistas intentan justificar la obra de Palma en el marco de una época convulsa en que el país está en búsqueda de definición identitaria en tanto que nación libre e independiente.

\section{Su carácter global e internacional}

La correspondencia epistolar de Palma lo hace habitante pleno del planeta dialogando con personajes de todas las latitudes. Hay que revisar su epistolario publicado por la Universidad Ricardo Palma en cuatro tomos. 
Su propia vida azarosa es el retrato de un país que pasaba del péndulo civil-militar, como de las asonadas de siempre, y Palma al frente de cada golpe. No es Palma un golpista sino un justiciero colocándose siempre al frente contra los dictadores. Habría que ver qué literato de la actualidad toma partido tan drásticamente como Palma. Es lo opuesto al diletante de cafetín que cree que la literatura es sinónimo de rendir culto al dios Baco y tomar un buen café.

En Palma es la vida misma la que lo inspira: su cuadro social de origen, su negritud así como el propio talento que trae a la vida y que coloca al servicio de su sociedad para retratarla, para que no se pierda nunca su recuerdo, su vida, su historia.

Sus tradiciones son capítulos de la historia patria recreados con fina ironía. Son crónicas aderezadas con su buen gusto, su chispa, su buen humor, a diferencia de González Prada, más bismarckeano, rígido, de verbo flamígero y censor, en una Lima que hablaba a media voz.

Palma es el criollo retozón, alegre, dicharachero, más cercano a la gente, mientras González Prada es el Catón maldecidor, sermoneador.

Hoy en esta "ciudad combi" y achorada, González Prada hubiera sufrido la tensión de su desbordante desorden y muerto de un infarto fulminante, mientras Palma aprovecharía los mil y un personajes populares para escribir sus historias. 


\section{Bibliografía}

Forgues, R. (2016). Las tradiciones de Ricardo Palma/ Disidencia y utopía. La voz de los orígenes. Ensayos literarios sobre creación e identidad en América Latina. Lima: Editorial Universitaria de la Universidad Ricardo Palma

Holguín, Callo O. (2001). Páginas sobre Ricardo Palma. Lima: Editorial Universitaria de la Universidad Ricardo Palma.

Mariátegui, J.C. (1973). Ricardo Palma, Lima y la Colonia. Siete ensayos de interpretación de la realidad peruana, edición 26, Lima: Biblioteca Amauta.

Palma, R. (1964). Tradiciones Peruanas Completas. Edición y prólogo de Edith Palma, nieta del autor. Con siete extensos apéndices y una selección de cartas del autor. Madrid: Ediciones Aguilar

Palma, R. (1968). Epistolario General. Lima: Editorial Universitaria de la Universidad Ricardo Palma.

Porras Barrenechea, R. (1935). Presentación y autocensura de la Pequeña antología de Lima (1535-1935). Madrid: Imprenta de Galo Sáez, Mezón de Paños.

Tanner Roy, L. (2005). El humor de la ironía y la sátira en las Tradiciones Peruanas. Lima: Editorial Universitaria de la Universidad Ricardo Palma

Zanutelli Rosas, M. (2011). El Senador Ricardo Palma y otros estudios. Lima: Editorial Universitaria de la Universidad Ricardo Palma

Zúñiga Segura, C. (2004). Ricardo Palma en La Marina. Lima: Editorial Universitaria de la Universidad Ricardo Palma

Recibido: 3 de octubre 2016 Aprobado: 5 de diciembre 2016 